\title{
PERSEPSI MAHASISWA TERHADAP FASILITAS DALAM WEB BASED LEARNING
}

\author{
Eveline Siregar \\ Cecep Kustandi
}

\begin{abstract}
This study aims at obtaining empirical data about student perceptions on the facilities of Indonesian web based learning at www.courses.web-bali.net developed by the Study Program of Educational Technology, School of Education, State University of Jakarta, and providing input to administrators and policy makers in its development. This study used survey methods of descriptive type. The data were collected by distributing questionnaires directly to 36 students selected as samples of 2008 academic years students who used www.courses.web-bali.net in semester 091 for Management of Information System course. Based on the data and analysis the study concluded that the student perceptions of Web Based Learning is catagorized good.
\end{abstract}

Key words: perception, web based learning, learning path.

Abstrak

Penelitian ini bertujuan untuk mendapatkan data empiris tentang persepsi mahasiswa terhadap fasilitasfasilitas dalam Web Based Learning Indonesia www.courses.web-bali.net yang dikembangkan Program Studi Teknologi Pendidikan, Fakultas llmu Pendidikan, Universitas Negeri Jakarta, serta memberi masukan kepada administrator dan pengambil kebijakan dalam pengembangannya. Penelitian ini menggunakan metode survei, tipe deskriptif. Proses pengumpulan data dilakukan melalui penyebaran angket secara langsung kepada responden sampling, yaitu terhadap mahasiswa yang sedang menggunakan www.courses.web-bali.net untuk kepentingan perkuliahan pada semester 091, yaitu mahasiswa angkatan 2008 yang sedang mengikuti mata kuliah Manajemen Sistem Informasi sebanyak 36 mahasiswa. Hasil penelitian menunjukan bahwa persepsi mahasiswa terhadap Web Based Learning Indonesia www.courses.web-bali.net, termasuk dalam kategori baik.

Kata-kata kunci: persepri, belajar berbasis web, alur pembelajaran.

\section{PENDAHULUAN}

Perkembangan ilmu pengetahuan dan teknologi telah membawa perubahan di hampir semua aspek kehidupan manusia di mana berbagai permasalahan hanya dapat dipecahkan dengan upaya penguasaan dan peningkatan ilmu pengetahuan dan teknologi. Ada beberapa kekuatan yang akan mengubah perjalanan hidup tentang cara belajar (Learning Revolution) sebagaimana digambarkan Dryen (2000), bahwa dunia sedang bergerak sangat cepat melalui titik balik sejarah yang menentukan. Oleh karena itu, peningkatan kualitas sumber daya manusia merupakan kenyataan yang harus dilakukan secara terencana, terarah, intensif, efektif, dan efisien dalam proses pembangunan, kalau tidak ingin bangsa ini kalah bersaing dalam menjalani era globalisasi tersebut.
Jurusan Kurikulum dan Teknologi Pendidikan Fakultas Ilmu Pendidikan, Universitas Negeri Jakarta, beberapa tahun terakhir sudah mengembangkan konsep pembelajaran web based learning sebagai bagian kecil dari perkuliahan secara elektronik mulai dari pendaftaran diri untuk mengikuti kuliah, konsultasi akademik, penyelesaian tugas-tugas dan penyerahannya, sampai dengan evaluasi kegiatan belajar mahasiswa yang bermuara pada peningkatan prestasi belajar.

Namun hal yang perlu menjadi pemikiran lebih lanjut adalah apakah mahasiswa menerima konsep pembelajaran tersebut, kemudian bagaimana persepsi mahasiswa terhadap Web Based Learning Jurusan Kurikulum dan Teknologi Pendidikan Fakultas Ilmu Pendidikan, Universitas Negeri Jakarta (www.courses.web-bali.net) ini?

Berdasarkan kajian analisis terhadap latar belakang di atas, diperlukan suatu kajian penelitian 
agar mampu memberikan masukan sebagai tindak lanjut dari pemanfaatan web based learning ini agar keberadaannya dirasakan berguna dan memberikan kontribusi positif dalam peningkatan prestasi belajar mahasiswa.

Berdasarkan latar belakang dan identifikasi masalah di atas, dapat dirumuskan sejumlah permasalahan yang lebih spesifik dan operasional untuk dikaji secara sistematis. Sejumlah pertanyaan yang akan dikaji dalam penelitian ini adalah (1) bagaimana persepsi mahasiswa terhadap mekanisme mendaftar (mendapatkan user account) pada Web Based Learning Indonesia (www.courses.web-bali.net), (2) bagaimana persepsi mahasiswa terhadap fasilitas learning path Web Based Learning Indonesia (www.courses.web-bali.net), (3) bagaimana persepsi mahasiswa terhadap fasilitas chat Web Based Learning Indonesia (www.courses.web-bali.net), (4) bagaimana persepsi mahasiswa terhadap fasilitas groups Web Based Learning Indonesia (www.courses.web-bali.net), dan (5) bagaimana persepsi mahasiswa terhadap fasilitas agenda Web Based Learning Indonesia (www.courses.webbali.net).

Penelitian ini akan sangat bermanfaat bagi stakeholder khususnya bagi program studi Teknologi Pendidikan Fakultas llmu Pendidikan, Universitas Negeri Jakarta yang di dalamnya mencakup programmer/administrator www.courses.web-bali.net, pengembang materi, dan pengambil kebijakan/ketua jurusan. Hasil penelitian ini akan menjadi masukan tentang gambaran persepsi mahasiswa terhadap fasilitas-fasilitas Web Based Learning Indonesia (www.courses.web-bali.net), sekaligus mendapat masukan dari mahasiswa tentang Web Based Learning Indonesia secara umum.

\section{KAJIAN PUSTAKA}

\section{Web Based Learning}

Pembelajaran elektronik atau web based learning telah dimulai pada tahun 1970-an (Waller and Wilson, 2001). Berbagai istilah digunakan untuk mengemukakan pendapat/gagasan tentang pembelajaran elektronik, antara lain on-line learning, internet-enabled learning, virtual learning, atau web-based learning.

Setidak-tidaknya dapat ditarik tiga hal penting sebagai persyaratan kegiatan belajar elektronik (web based learning), yaitu (a) kegiatan pembelajaran dilakukan melalui pemanfaatan jaringan ("jaringan" dalam uraian ini dibatasi pada penggunaan internet. Jaringan dapat saja mencakup LAN atau WAN).
(Website eLearners.com), (b) tersedianya dukungan layanan belajar yang dapat dimanfaatkan oleh peserta belajar, misalnya CD-ROM atau bahan cetak, dan (c) tersedianya dukungan layanan tutor yang dapat membantu peserta belajar apabila mengalami kesulitan.

Di samping ketiga persyaratan tersebut di atas masih dapat ditambahkan persyaratan lainnya, seperti adanya (a) lembaga yang menyelenggarakan/ mengelola kegiatan web based learning, (b) sikap positif dari peserta didik dan tenaga kependidikan terhadap teknologi komputer dan internet, (c) rancangan sistem pembelajaran yang dapat dipelajari/diketahui oleh setiap peserta belajar, (d) sistem evaluasi terhadap kemajuan atau perkembangan belajar peserta belajar, dan (e) mekanisme umpan balik yang dikembangkan oleh lembaga penyelenggara.

Instructional ai

Dengan demikian, secara sederhana dapatlah (e.g. collaboratic dikatakan bahwa pembelajaran elektronik (web based learning) merupakan kegiatan pembelajaran yang memanfaatkan jaringan (Internet, LAN, dan WAN) sebagai metode penyampaian, interaksi, dap asi serta didukung oleh berbagai bentuk lay ajar lainnya (Brown, 2000; Feasey, 2001). Jalam uraian lebih lanjut, istilah "web based lea ing", "online learning" atau "pembelajaran ele Qnik" akan digunakan secara bergantian namur pengertian yang sama seperti yang telah seperti pada bagan berikut ini.

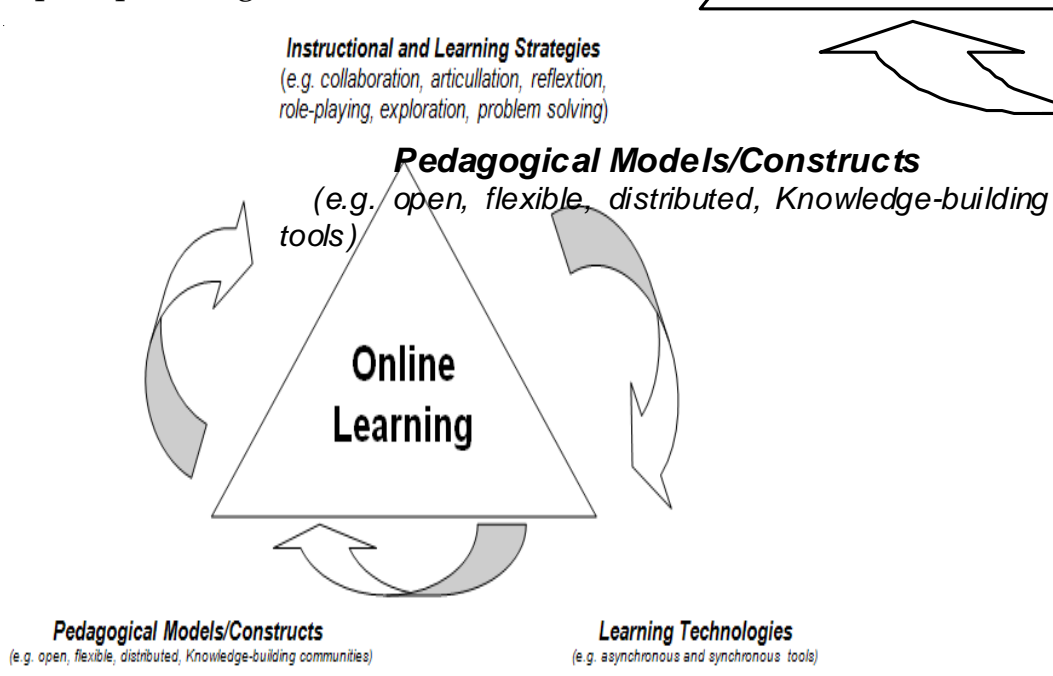

Gambar 1. Komponen Pembelajaran yang Memanfaatkan Jaringan

\section{Fungsi Pembelajaran Elektronik}

Setidaknya ada tiga fungsi pembelajaran elektronik terhadap kegiatan pembelajaran di dalam kelas (classroom instruction), yaitu sebagai suplemen yang sifatnya pilihan/opsional, pelengkap 
(komplemen), atau pengganti (substitusi) (Siahaan, 2002).

\section{Suplemen (Tambahan)}

Dikatakan berfungsi sebagai suplemen (tambahan) apabila peserta didik mempunyai kebebasan memilih, apakah akan memanfaatkan materi pembelajaran elektronik atau tidak. Dalam hal ini, tidak ada kewajiban/keharusan bagi peserta didik untuk mengakses materi pembelajaran elektronik. Sekalipun sifatnya opsional, peserta didik yang memanfaatkannya tentu akan memiliki tambahan pengetahuan atau wawasan

\section{Komplemen (Pelengkap)}

Dikatakan berfungsi sebagai komplemen (pelengkap) apabila materi pembelajaran elektronik diprogramkan untuk melengkapi materi pembelajaran

nd Learning Strádegiejterima siswa di dalam kelas (Lewis, 2002). n, articullation, remai komplemen berarti materi pembelajaran loration, problem şlelving) onik diprogramkan untuk menjadi materi reinforcement (pengayaan) atau remedial bagi peserta didik di dalam mengikuti kegiatan pembelajaran kon

Maten embelajaran elektronik dikatakan sebagai enrichme apabila peserta didik dengan cepat menguasai/me ahami materi pelajaran yang lisampaikan su secara tatap muka (fast learners) erikan ke atan untuk mengakses materi elajaran ronik yang memang secara khusus ngkan. Njuannya agar semakin memantapkan tingkat penguasaan peserta didik terhadap materi pelajaran yang disajikan guru di dalam kelas.

Dikatakan sebagai program remedial, apabila kepada pesarning Tidpchnoloqies galami kesulitan memahami materi pelajaran yang disajikan guru secara tatap muka di kelas (slow learners) diberikan kesempatan untuk memanfaatkan materi pembelajaran elektronik yang memang secara khusus dirancang. Tujuannya agar peserta didik semakin lebih mudah memahami materi pelajaran yang disajikan guru di kelas.

3. Substitusi (Pengganti)

Beberapa perguruan tinggi di negara-negara maju memberikan beberapa alternatif model kegiatan pembelajaran/perkuliahan kepada para mahasiswanya. Tujuannya agar para mahasiswa dapat secara fleksibel mengelola kegiatan perkuliahannya sesuai dengan waktu dan aktivitas lain sehari-hari mahasiswa. Ada tiga alternatif model kegiatan pembelajaran yang dapat dipilih peserta didik, yaitu (1) sepenuhnya secara tatap muka (konvensional), (2) sebagian secara tatap muka dan sebagian lagi melalui internet, atau bahkan (3) sepenuhnya melalui internet.

\section{Manfaat Web Based Learning?}

Web based learning mempermudah interaksi antara peserta didik dengan bahan/materi pelajaran. Demikian juga, interaksi antara peserta didik dengan dosen/guru/instruktur maupun antara sesama peserta didik. Peserta didik dapat saling berbagi informasi atau pendapat mengenai berbagai hal yang menyangkut pelajaran ataupun kebutuhan pengembangan diri peserta didik. Guru atau instruktur dapat menempatkan bahan-bahan belajar dan tugas-tugas yang harus dikerjakan oleh peserta didik di tempat tertentu dalam web untuk diakses oleh para peserta didik. Sesuai dengan kebutuhan, guru/instruktur dapat pula memberikan kesempatan kepada peserta didik untuk mengakses bahan belajar tertentu maupun soal-soal ujian yang hanya dapat diakses oleh peserta didik sekali saja dan dalam rentangan waktu tertentu pula (Website Kudos, 2002).

Secara lebih rinci, manfaat web based learning dapat dilihat dari dua sudut, yaitu dari sudut peserta didik dan guru:

\section{Dari Sudut Peserta Didik}

Dengan kegiatan web based learning dimungkinkan berkembangnya fleksibilitas belajar yang tinggi. Artinya, peserta didik dapat mengakses bahan-bahan belajar setiap saat dan berulang-ulang. Peserta didik juga dapat berkomunikasi dengan guru/ dosen setiap saat. Dengan kondisi yang demikian ini, peserta didik dapat lebih memantapkan penguasaannya terhadap materi pembelajaran.

Manakala fasilitas infrastruktur tidak hanya tersedia di daerah perkotaan tetapi telah menjangkau daerah kecamatan dan pedesaan, maka kegiatan web based learning akan memberikan manfaat (Brown, 2000) kepada peserta didik yang (1) belajar di sekolahsekolah kecil di daerah-daerah miskin untuk mengikuti mata pelajaran tertentu yang tidak dapat diberikan oleh sekolahnya, (2) mengikuti program pendidikan keluarga di rumah (home schoolers) untuk mempelajari materi pembelajaran yang tidak dapat diajarkan oleh para orangtuanya, seperti bahasa asing dan keterampilan di bidang komputer, (3) merasa phobia dengan sekolah, atau peserta didik yang dirawat di rumah sakit maupun di rumah, yang putus sekolah tetapi berminat melanjutkan pendidikannya, yang dikeluarkan oleh sekolah, maupun peserta didik yang berada di berbagai daerah atau bahkan yang berada di luar negeri, dan (4) tidak tertampung di sekolah konvensional untuk mendapatkan pendidikan.

\section{Dari Sudut Guru/Dosen}

Dengan adanya kegiatan web based learning (Soekartawi, 2002), beberapa manfaat yang diperoleh 
guru/dosen/instruktur antara lain adalah bahwa guru/dosen/ instruktur dapat: (1) lebih mudah melakukan pemutakhiran bahan-bahan belajar yang menjadi tanggung-jawabnya sesuai dengan tuntutan perkembangan keilmuan yang terjadi, (2) mengembangkan diri atau melakukan penelitian guna peningkatan wawasannya karena waktu luang yang dimiliki relatif lebih banyak, (3) mengontrol kegiatan belajar peserta didik. Bahkan guru/dosen/instruktur juga dapat mengetahui kapan peserta didiknya belajar, topik apa yang dipelajari, berapa lama sesuatu topik dipelajari, serta berapa kali topik tertentu dipelajari ulang, (4) mengecek apakah peserta didik telah mengerjakan soal-soal latihan setelah mempelajari topik tertentu, dan (5) memeriksa jawaban peserta didik dan memberitahukan hasilnya kepada peserta didik.

\section{Penyelenggaraan Web Based Learning}

Web based learning tampaknya lebih banyak digunakan di dunia bisnis. Dari penelitian yang dilaksanakan oleh Diane E. Lewis pada tahun 2001 (Lewis, 2002) diketahui bahwa sekitar 42\% dari 671 perusahaan yang diteliti telah menerapkan program pembelajaran elektronik dan sekitar 12\% lainnya berada pada tahap persiapan/perencanaan. Di samping itu, sekitar $90 \%$ kampus perguruan tinggi nasional juga mengandalkan berbagai bentuk pembelajaran elektronik, baik untuk membelajarkan para mahasiswanya maupun untuk kepentingan komunikasi antara sesama dosen. Kemajuan yang demikian ini sangat ditentukan oleh sikap positif masyarakat pada umumnya, pimpinan perusahaan, peserta didik, dan tenaga kependidikan pada khususnya terhadap teknologi komputer dan internet. Sikap positif masyarakat yang telah berkembang terhadap teknologi komputer dan internet antara lain tampak dari semakin banyaknya jumlah pengguna dan penyedia jasa internet.

Peningkatan jumlah pengguna internet sangat menakjubkan di berbagai negara, terutama di lingkungan negara-negara berkembang. Alexander Downer, Menteri Luar negeri Australia, mengemukakan bahwa jumlah pengguna internet dalam kurun waktu 1998-2000 meningkat dari 1,7 juta menjadi 9,8 juta orang (Brazil), dari 3,8 juta menjadi 16,9 juta orang (China), dan dari 3.000 menjadi 25.000 orang (Uganda) (Downer, 2001).

Selain sikap positif peserta didik dan tenaga kependidikan, alasan/pertimbangan lain untuk menggunakan web based learning, di antaranya adalah karena: (a) harga perangkat komputer yang semakin lama semakin relatif murah (tidak lagi diperlakukan sebagai barang mewah), (b) peningkatan kemampuan perangkat komputer yang mampu mengolah data lebih cepat dan kapasitas penyimpanan data yang semakin besar; (c) memperluas akses atau jaringan komunikasi, (d) memperpendek jarak dan mempermudah komunikasi, dan (e) mempermudah pencarian atau penelusuran informasi melalui internet.

\section{Platform Claroline}

Terdapat banyak cara dalam mengembangkan sebuah sistem pembelajaran online atau E-learning, salah satunya adalah dengan menggunakan aplikasi LMS (Learning Management System), yakni sebuah perangkat untuk membuat materi pembelajaran berbasis web yang mengelola kegiatan pembelajaran beserta hasilnya dan memfasilitasi interaksi antarguru dan siswa, antarguru dan guru, serta antarsiswa dan siswa. LMS mendukung berbagai aktivitas, antara lain administrasi, peyampaian materi pembelajaran, penilaian (tugas dan kuis), pelacakan/tracking \& monitoring, kolaborasi, serta komunikasi/interaksi. Saat ini tersebar banyak aplikasi-aplikasi LMS yang tersedia di internet, baik yang bersifat gratis (open source) maupun yang komersil atau berbayar, di antaranya: Moodle (http:/ / www.moodle.org), ATutor (http://www.atutor.ca), Claroline (http:// www.claroline.net), ClaSS (http://www.laex.org/ class), SiteAtSchool (http://www.siteatschool.org), Docebo (http://www.docebo.org/doceboCms), eCollege (http:/ / www.ecollege.com), Dokeos (http:/ / www.dokeos.com), Blackboard (http:// www.blackboard.com), dan sebagainya. Dari salah satu aplikasi LMS tersebut yang paling populer dan yang paling banyak digunakan adalah LMS Claroline.

Selain tersedia dengan gratis, fitur-fitur yang ditawarkan Claroline relatif lebih lengkap dan mudah digunakan dibandingkan dengan aplikasi lainnya. Claroline dapat dengan mudah dipakai untuk mengembangkan sistem E-learning. Dengan Claroline portal E-learning dapat dimodifikasi sesuai kebutuhan. Melalui aplikasi E-learning dengan Moodle ini para dosen dapat mengelola materi perkuliahan, yakni menyusun silabi, mengunggah (upload) materi perkuliahan, memberikan tugas kepada mahasiswa, menerima pekerjaan mahasiswa, membuat tes/kuis, memberikan nilai, memonitor keaktifan mahasiswa, mengolah nilai mahasiswa, berinteraksi dengan mahasiswa dan sesama dosen melalui forum diskusi dan chat, dan sebagainya. Di sisi lain, mahasiswa dapat mengakses informasi dan materi pembelajaran, berinteraksi dengan sesama mahasiswa dan dosen, melakukan transaksi tugas-tugas perkuliahan, mengerjakan tes/kuis, melihat pencapaian hasil 
belajar, dan sebagainya. Salah satu keuntungan bagi dosen yang membuat mata kuliah online berbasis LMS adalah kemudahan. Dosen tidak perlu mengetahui sedikitpun tentang bahasa pemrograman web, sehingga waktu yang ada dapat dimanfaatkan lebih banyak untuk memikirkan konten (isi) pembelajaran yang akan disampaikan. Beberapa keunggulan dan kelebihan yang didapatkan dengan membangun LMS dengan menggunakan Claroline diantaranya, adalah sebagai berikut

1) Sederhana, efisien, ringan, dan kompatibel dengan banyak browser dan operating system.

2) Mudah cara instalasinya serta mendukung banyak bahasa, lebih dari 70 bahasa dari 195 negara, termasuk Bahasa Indonesia.

3) Tersedianya manajemen situs untuk pengaturan situs keseluruhan, mengubah thema atau tampilan situs, menambah modul, dan sebagainya.

4) Tersedianya manajemen user/pengguna.

5) Tersedianya manajemen mata kuliah/bahan ajar, penambahan jenis mata kuliah/bahan ajar, pengurangan atau pengubahan mata kuliah/ bahan ajar.

6) Tersedianya fasilitas user account, learning path, chat, groups, agenda, serta fasilitas lain yang masih mungkin ditambahkan.

7) Gratis dan merupakan open source software.

Web-BaLi (www.courses.web-bali.net)

Web Based Learning jurusan Kurikulum dan Teknologi Pendidikan, Fakultas llmu Pendidikan, Universitas Negeri Jakarta dengan homepage www.courses.web-bali.net serta situs pembelajaran www.courses.web-bali.net, merupakan suatu sistem pembelajaran berbasis jaringan yang dikembangkan jurusan Kurikulum dan Teknologi Pendidikan, Fakultas llmu Pendidikan, Universitas Negeri Jakarta. Adapun platform yang digunakan sebagai learning content management systems (LCMS) ini menggunakan Claroline berlandaskan beberapa kriteria. Pertama, acuan definisi teknologi pendidikan dan teknologi pembelajaran dari AECT tahun 1994 dan 2004 yang berprinsip menekankan proses belajar sebagai aspek terpenting dalam adopsi suatu teknologi. Kedua, prinsip desain pembelajaran yang mengikuti teori-teori belajar dan pembelajaran serta temuan ilmiah di dalam nya misalnya terkait dengan alur penyajian materi, fungsi media pembelajaran dan sumber belajar, analisis pembelajaran, desain pesan, evaluasi belajar dan pembelajaran, dan sebagainya. Ketiga, aspek teknologi itu sendiri yaitu platform claroline yang dinilai cukup ringan dan relatif mudah karena tidak membebani dengan slot data yang tidak terkait dengan belajar dan pembelajaran secara langsung. Keempat, platform ini dapat diunduh gratis.

\section{Persepsi}

Persepsi pada hakikatnya adalah merupakan proses penilaian seseorang terhadap objek tertentu. Menurut Young (1956), persepsi merupakan aktivitas mengindera, mengintegrasikan dan memberikan penilaian pada objek-objek fisik maupun objek sosial, dan penginderaan tersebut tergantung pada stimulus fisik dan sosial yang ada di lingkungannya. Sensasisensasi dari lingkungan akan diolah bersama-sama dengan hal-hal yang telah dipelajari sebelumnya baik hal itu berupa harapan-harapan, nilai-nilai, sikap, ingatan, dan lain-lain. Branca (1965) mengemukakan: Perceptions are orientative reactions to stimuli. They have in past been determined by the past history and the present attitude of the perceiver. Sedangkan menurut Wagito (1981) menyatakan bahwa persepsi merupakan proses psikologis dan hasil dari penginderaan serta proses terakhir dari kesadaran, sehingga membentuk proses berpikir.

Di dalam proses persepsi individu dituntut untuk memberikan penilaian terhadap suatu yang dapat bersifat positif/negatif, senang atau tidak senang dan sebagainya. Dengan adanya persepsi maka akan terbentuk sikap, yaitu suatu kecenderungan yang stabil untuk berlaku atau bertindak secara tertentu di dalam situasi yang tertentu pula (Polak, 1976). Dalam hal ini Crow (1972) menyatakan persepsi, sebagai berikut.

A percept is an organized totality rather than the sum total of individual sensory experinces. In perception, an individual first gains a general impression of the outline of on ogject or situation, (which is) the percepts quality of organized totality.

Sementara itu, Branca (1965) mengemukakan persepsi sebagai berikut:

Perceptions are sensations with the addition of same sort of interpretation or indication of the sensation or the stimulus source of the sensation. The interpretation of the identification is the product past learning.

Dengan demikian, persepsi merupakan suatu fungsi biologis (melalui organ-organ sensoris) yang memungkinkan individu menerima dan mengolah informasi dari lingkungan dan mengadakan perubahan-perubahan di lingkungannya (Eytonck, 1972).

Istilah persepsi adalah suatu proses aktivitas seseorang dalam memberikan kesan, penilaian, pendapat, merasakan dan menginterpretasikan sesuatu berdasarkan informasi yang ditampilkan dari sumber lain (yang dipersepsi). Melalui persepsi, 
individu dapat mengenali dunia sekitarnya, yaitu seluruh dunia yang terdiri dari benda serta manusia dengan segala kejadian-kejadiannya (Meider, 1958).

Dengan persepsi, manusia dapat berinteraksi dengan dunia sekelilingnya, khususnya antarmanusia. Dalam kehidupan sosial di kelas tidak lepas dari interaksi antara mahasiswa dengan mahasiswa, antara mahasiswa dengan dosen. Adanya interaksi antarkomponen yang ada di dalam kelas menjadikan masing-masing komponen (mahasiswa dan dosen) akan saling memberikan tanggapan, penilaian, dan persepsinya. Adanya persepsi ini adalah penting agar dapat menumbuhkan komunikasi aktif, sehingga dapat meningkatkan kapasitas belajar di kelas. Persepsi adalah suatu proses yang kompleks di mana manusia menerima dan menyadap informasi dari lingkungan (Fleming \& Levie, 1978).

Persepsi juga merupakan proses psikologis sebagai hasil penginderaan serta proses terakhir dari kesadaran, sehingga membentuk proses berpikir. Persepsi seseorang akan mempengaruhi proses belajar (minat) dan mendorong mahasiswa untuk melaksanakan sesuatu (motivasi) belajar. Oleh karena itu, menurut Walgito (1981), persepsi merupakan kesan yang pertama untuk mencapai suatu keberhasilan. Persepsi seseorang dalam menangkap informasi dan peristiwa-peristiwa menurut Muhyadi (1989) dipengaruhi oleh tiga faktor, yaitu 1) orang yang membentuk persepsi itu sendiri, khususnya kondisi intern (kebutuhan, kelelahan, sikap, minat, motivasi, harapan, pengalaman masa lalu, dan kepribadian), 2) stimulus yang berupa objek maupun peristiwa tertentu (benda, orang, proses, dan Iain-lain), 3) stimulus di mana pembentukan persepsi itu terjadi baik tempat, waktu, serta suasana (sedih, gembira, dan lain-lain).

\section{METODOLOGI PENELITIAN}

Tujuan penelitian ini adalah untuk mengetahui persepsi mahasiswa tentang adanya web based learning yang dikembangkan di jurusan Kurikulum dan Teknologi Pendidikan, Fakultas llmu Pendidikan, Universitas Negeri Jakarta.

Secara khusus, penelitian ini dilaksanakan dengan tujuan, sebagai berikut.

1) Mendapatkan data empiris tentang persepsi mahasiswa terhadap fasilitas-fasilitas dalam webBaLi.

2) Memberi masukan kepada administrator dan pengambil kebijakan dalam pengembangan web-

\section{BaLi.}

Penelitian ini dilakukan di lingkungan jurusan Kurikulum dan Teknologi Pendidikan, Fakultas llmu Pendidikan, Universitas Negeri Jakarta. Sedangkan waktu penelitian dilaksanakan selama 4 bulan, yaitu Mei 2009 sampai Agustus 2009.

Sesuai dengan tujuan penelitian ini, maka yang menjadi populasi target dalam penelitian ini adalah seluruh mahasiswa Program Studi Teknologi Pendidikan. Sedangkan populasi terjangkaunya adalah mahasiswa yang sudah memiliki user acount dan pernah mengakses web-BaLi.

Dengan populasi terjangkau yang dimaksud, maka yang menjadi sampel penelitian ini adalah mahasiswa yang sedang menggunakan web-BaLi untuk kepentingan perkuliahan pada semester 91 yaitu mahasiswa angkatan 2008 yang sedang mengikuti mata kuliah Manajemen Sistem Informasi dan Pembelajaran sebanyak 36 orang Mahasiswa.

Penelitian ini menggunakan metode survei, tipe deskriptif. Penelitian akan dilaksanakan di jurusan Kurikulum dan Teknologi Pendidikan, Universitas Negeri Jakarta, dengan subjek utamanya adalah mahasiswa jurusan Kurikulum dan Teknologi Pendidikan, Universitas Negeri Jakarta. Data yang diperlukan dalam penelitian ini didapatkan dari pengisian angket.

Proses pengumpulan data dilakukan melalui penyebaran angket secara langkung kepada responden Sampling.

Instrumen yang dikembangkan dan digunakan untuk pengumpulan data dalam bentuk angket. Instrumen yang dikembangkan dengan mengacu pada kerangka teori dan kebutuhan informasi yang diperlukan berkenaan dengan fasilitas-fasilitas dalam web-BaLi www.courses.web-bali.net berjumlah 40 butir pertanyaan.

Data yang terkumpul dianalisis dengan menggunakan teknik analisis deskriptif kuantitatif. Melalui teknik ini, data yang diperoleh dengan angket akan ditabulasi untuk masing-masing item, kemudian akan dicari banyaknya jawaban atas setiap item, dan dicari persentasenya.

Penelitian ini dilakukan selama bulan MeiAgustus tahun 2009. Kegiatan penelitian ini dengan judul persepsi mahasiswa tentang adanya web based learning www.courses.web-bali.net yang dikembangkan di jurusan kurikulum dan Teknologi Pendidikan, Fakultas Ilmu Pendidikan, Universitas Negeri Jakarta ini dimulai dari kegiatan persiapan, pengumpulan data, pengolahan data, dan pelaporan hasil penelitian. 
HASIL DAN PEMBAHASAN

\section{Deskripsi Data}

Data hasil penelitian mengenai persepsi mahasiswa terhadap web based learning www.courses.web-bali.net diperoleh dari hasil penelitian terhadap lima aspek, yaitu aspek persepsi mahasiswa terhadap Mekanisme Mendaftar (mendapatkan user account), persepsi mahasiswa terhadap Fasilitas Learning Path www.courses.web-bali.net, persepsi mahasiswa terhadap Fasilitas Chat www.courses.webbali.net, persepsi mahasiswa terhadap Fasilitas Groups www.courses.web-bali.net, dan aspek persepsi mahasiswa terhadap Fasilitas Agenda www.courses.webbali.net. Untuk mengukur skor yang didapat masingmasing aspek tersebut digunakan skala pengukuran dengan lima pilihan jawaban.

Dari hasil perhitungan terhadap data hasil angket diketahui bahwa :

Pertama, aspek persepsi mahasiswa terhadap Mekanisme Mendaftar (mendapatkan user account), dengan delapan pertanyaan yang diajukan, diperoleh skor jawaban sebesar 1163, jika dibandingkan dengan skor ideal 46520 ( 8 X 5 X 36 ), maka diperoleh skor kecenderungan sebesar 0,808 atau 80,8\%, dalam arti bahwa tingkat persepsi mahasiswa terhadap Mekanisme Mendaftar (mendapatkan user account) termasuk pada katagori baik.

Kedua, aspek persepsi mahasiswa terhadap Fasilitas Learning Path www.courses.web-bali.net, dengan delapan pertanyaan yang diajukan diperoleh skor jawaban sebesar 1115, jika dibandingkan dengan skor ideal 1440 ( 8 X 5 X 36 ), maka diperoleh skor kecenderungan sebesar 0,774 atau $77,4 \%$, dalam arti bahwa tingkat persepsi mahasiswa terhadap Fasilitas Learning Path www.courses.web-bali.net termasuk pada katagori baik.

Ketiga, aspek persepsi mahasiswa terhadap Fasilitas Chat www.courses.web-bali.net, dengan delapan pertanyaan yang diajukan diperoleh skor jawaban sebesar 1172, jika dibandingkan dengan skor ideal 1440 ( 8 X 5 X 36 ), maka diperoleh skor kecenderungan sebesar 0,814 atau $81,4 \%$, dalam arti bahwa tingkat persepsi mahasiswa terhadap Fasilitas Chat www.courses.web-bali.net termasuk pada katagori baik.

Keempat, aspek persepsi mahasiswa terhadap Fasilitas Groups www.courses.web-bali.net, dengan delapan pertanyaan yang diajukan, diperoleh skor jawaban sebesar 1099, jika dibandingkan dengan skor ideal 1440 (8 X 5 X 36), maka diperoleh skor kecenderungan sebesar 0,760 atau $76,0 \%$, dalam arti bahwa tingkat persepsi mahasiswa terhadap Fasilitas Groups www.courses.web-bali.net masuk pada katagori baik.

Kelima, aspek persepsi mahasiswa terhadap Fasilitas Agenda www.courses.web-bali.net, dengan delapan pertanyaan yang diajukan, diperoleh skor jawaban sebesar 1065, jika dibandingkan dengan skor ideal 1440 ( 8 X 5 X 36), maka diperoleh skor kecenderungan sebesar 0,740 atau 74,0 \%, dalam arti bahwa tingkat persepsi mahasiswa terhadap Fasilitas Agenda www.courses.web-bali.net masuk pada katagori baik

\section{Analisis Data}

Dengan memperhatikan perolehan skor kecenderungan pada masing-masing aspek tadi, maka skor kecenderungan Persepsi Mahasiswa Terhadap Web Based Learning termasuk pada katagori baik.

Selanjutnya, untuk mengetahui gambaran secara umum mengenai Persepsi Mahasiswa Terhadap web based learning www.courses.web-bali.net, maka akan ditampilkan data yang terdiri dari ukuran gejala pusat, ukuran penyebaran data, ukuran model, dan distribusi frekuensi beserta histogramnya. Dalam ukuran gejala pusat disajikan skor rata-rata hitung, modus, dan median, sedangkan ukuran penyimpangan disajikan skor simpangan baku, rentang, nilai maksimum dan minimum, kemiringan (sekweniss), dan kurtosis akan ditampilkan sebagai gambaran model.

Skor rata-rata Persepsi Mahasiswa Terhadap Web Based Learning www.courses.web-bali.net sebesar 155,94 . Jika rata-rata tersebut dibandingkan dengan skor maksimal ideal 200, maka skor kecenderungan Persepsi Mahasiswa Terhadap Web Based Learning www.courses.web-bali.net sebesar 0,7797 atau 77,97\%. Hal ini membuktikan bahwa Persepsi Mahasiswa Terhadap Web Based Learning www.courses.web-bali.net termasuk dalam kategori baik.

Berdasarkan hasil analisis data di atas, dapat ditarik beberapa kesimpulan, sebagai berikut.

Persepsi mahasiswa terhadap mekanisme mendaftar (mendapatkan user account) untuk memanfaatkan fasilitas www.courses.web-bali.net (web based learning jurusan Kurikulum dan Teknologi Pendidikan, Fakultas llmu Pendidikan, Universitas Negeri Jakarta), sebanyak 55,56\% menyatakan tidak mengalami kesulitan, yang memiliki persepsi sangat tinggi sebanyk 33,33\%, dan hanya $11.11 \%$ yang memandang sedang dalam mekanisme mendafar di www.courses.web-bali.net. Kemudian terungkap pula kebanyakan permasalahan mahasiswa adalah ketika lupa akan password yang digunakan untuk login untuk 
kedua kalinya.

Persepsi mahasiswa terhadap fasilitas learning path www.courses.web-bali.net (Web Based Learning jurusan Kurikulum dan Teknologi Pendidikan, Fakultas llmu Pendidikan, Universitas Negeri Jakarta), sebanyak 75,00\% menyatakan persepsi yang tinggi, yang memiliki persepsi sangat tinggi sebanyk 16,67\%, dan hanya $8.33 \%$ yang memandang sedang terhadap fasilitas learning path di www.courses.web-bali.net. Kemudian terungkap pula kebanyakan permasalahan mahasiswa adalah ketika tidak mencermati bahwa learning path merupakan gambaran progres yang didapat setelah mengakses materi dan menyelesaikan modul evaluasi, sehingga banyak di antara mahasiswa yang melewatkan beberapa materi dalam arti lain tidak menuntaskan sampai akhir.

Persepsi mahasiswa terhadap fasilitas chat www.courses.web-bali.net (web based learning jurusan Kurikulum dan Teknologi Pendidikan, Fakultas llmu Pendidikan, Universitas Negeri Jakarta), sebanyak $63.89 \%$ menyatakan persepsi yang tinggi, yang memiliki persepsi sangat tinggi sebanyak $27.78 \%$ dan hanya 8.33 \% yang memandang sedang terhadap fasilitas chat di Web-BaLi. Kemudian terungkap pula kebanyakan permasalahan mahasiswa dalam fasilitas ini adalah kadang tidak bisa menggunakan fasilitas ini pada beberapa browser tertentu, misalnya pada Safari dan internet explorer versi rendah.

Persepsi mahasiswa terhadap fasilitas groups www.courses.web-bali.net (web based learning jurusan Kurikulum dan Teknologi Pendidikan, Fakultas llmu Pendidikan, Universitas Negeri Jakarta), sebanyak $63.89 \%$ menyatakan persepsi yang tinggi, yang memiliki persepsi sangat tinggi sebanyak $16.67 \%$ dan hanya $2.78 \%$ yang memandang rendah terhadap fasilitas groups di www.courses.web-bali.net. Kemudian terungkap pula kebanyakan permasalahan mahasiswa dalam fasilitas ini adalah karena hampir tidak pemahnya dosen untuk membagi mahasiswa dalam kelompok sehingga fasilitas ini jarang dimanfaatkan.

Persepsi mahasiswa terhadap fasilitas agenda www.courses.web-bali.net (wb based learning jurusan Kurikulum dan Teknologi Pendidikan, Fakultas llmu Pendidikan, Universitas Negeri Jakarta), sebanyak $75.00 \%$ menyatakan persepsi yang tinggi, yang memiliki persepsi sangat tinggi sebanyak $13.89 \%$ dan hanya $2.78 \%$ yang memandang rendah terhadap fasilitas agenda di www.courses.web-bali.net. Kemudian terungkap pula, kebanyakan permasalahan mahasiswa dalam fasilitas ini adalah hanya satu orang dosen yang mengagendakan pertemuan, penugasan, dan ujian.

\section{PENUTUP}

\section{Kesimpulan}

Hasil penelitian menunjukan bahwa persepsi mahasiswa terhadap web based learning Indonesia www.courses.web-bali.net diperoleh dari hasil penelitian terhadap lima aspek, yaitu aspek persepsi mahasiswa terhadap Mekanisme Mendaftar (mendapatkan user account), Learning Path, Chat, Groups, Agenda web based learning Indonesia www.courses.web-bali.net, diperoleh skor rata-rata sebesar 155,94. Jika rata-rata tersebut kita bandingkan dengan skor maksimal ideal 200, maka skor kecenderungan Persepsi Mahasiswa terhadap web based learning sebesar 0,7797 atau 77,97\%. Hal ini membuktikan bahwa persepsi mahasiswa terhadap web based learning termasuk dalam kategori baik.

\section{Saran}

Berdasarkan kesimpulan di atas, dapat diajukan saran/rekomendasi sebagai berikut.

1. Bagi Universitas Negeri Jakarta

Melihat sangat tingginya kebutuhan mahasiswa akan keberadaan akses internet maka sebaiknya pihak universitas memperhatikan penambahan fasilitas bandwidth, karena jumlah kebutuhan akses mahasiswa tidak seimbang dengan jumlah bandwidth yang tersedia sekarang.

2. Bagi Program Studi Teknologi Pendidikan

Melihat sangat tingginya persepsi mahasiswa terhadap www.courses.web-bali.net, perlu ada langkahlangkah kongkrit yang mendorong dosen-dosen untuk mengoptimalkan fasilitas www.courses.web-bali.net ini, sehingga semua mata kuliah sudah bisa di akses mahasiswa.

3. Bagi Mahasiswa

Mahasiswa hendaknya lebih konsen memanfaatkan fasilitas-fasilitas ini secara menyeluruh tanpa tekanan/perintah dari dosen untuk mengakses www.courses.web-bali.net ini.

\section{Bagi Para Dosen}

Para dosen hendaknya memanfaatkan fasilitas ini sebagai suatu bentuk pembelajaran yang lebih variatif sebagai tuntutan dunia teknologi yang semakin berkembang.

\section{DAFTAR PUSTAKA}

Bates, A. W. (1995). Technology, open learning and distance education. London: Routledge.

Branca. A.A. (1965). Psychology: The science of behavior. Boston: Allyn and Bacon Inc.

Crow, L. D. \& A. C. Crow .(1973). Educational psychology. 
New Delhi: Eurasia Publishing House.

Downer, A. (2001). The virtual colombo plan-bringing the digital divide. Diakses pada tanggal 24 Februari 2009 dari http:/ / www.ausaid.gov.au/

Dryden, G. \& Vos, J. (2001). Revolusi cara belajar (The learning revolution): Belajar akan efektif jika anda dalam keadaan "fun" bagian I: Keajaiban pikiran. Bandung: Kaifa

Eytonck. (1972). Psychology of personality. New York: Prentice Hall, Inc.

Feasey, D. 2001. Web based learning. Diakses pada tanggal 20 Agustus 2007 dari http:// eyepopping.manilasites.com/profiles.

Fleming, M., \& Levie, H. (1978). Instructional message design: Principles from the behavioral sciences. Englewood Cliffs, New Jersey: Educational Technology Publications.

Hardhono, A.P. (2002). Potensi teknologi komunikasi dan informasi dalam mendukung penyelenggaraan pendidikan jarak jauh di Indonesia. Jurnal Pendidikan Terbuka dan Jarak Jauh Vol. 3, No. 1 Maret 2002. Tangerang: Pusat Studi Indonesia, Lembaga Penelitian Universitas Terbuka.

Kudos (2007). What is web based learning. Diakses pada tanggal 25 September 2007 dari http:// www.kudos-idd.com/learning_solutions/ definition.

Lewis, D. E. (2002). A departure from training by the book, more companies seeing benefits of e-Learning. Diakses pada tanggal 24 Februari 2009 dari http: // bostonworks.boston.com/globe/ articles/052602/elearn.html.

McCracken, H. (2002). The importance of learning communities in motivating and retaining online learners. University of Illinois at Springfield.

Muhyadi. (1989). Organisasi, teori, struktur dan proses, Jakarta: Departemen Pendidikan dan Kebudayaan. Direktorat Jenderal Pendidikan Tinggi Proyek Pengembangan Pendidikan Tenaga Kependidikan.

Polak, R. A. (1976). Interdependent preferences. American Economic Review 66 (3, June): 309-320.

Rankin, W. P. (2002). Maximal interaction in the virtual classroom: Establishing connections with adult online learners. Diakses pada tanggal 20 September 2007 dari http://lppm.ut.ac.id/ htmpublikasi/siahaan.htm

Reddy, V. V. \& Manjulika, S. (2002). From face-to-face to virtual tutoring: Exploring the potentials of web based learning support. Indira Gandhi National Open University

Siahaan, S. (2002). Studi penjajagan tentang kemungkinan pemanfaatan internet untuk pembelajaran di SLTA di wilayah Jakarta dan sekitarnya. Jurnal Pendidikan dan Kebudayaan, Tahun ke-8, No 039, November 2002:: Badan Penelitian dan Pengembangan-Departemen Pendidikan Nasional

Soekartawi. 2002. Prospek pembelajaran jarak jauh melalui internet. Invited Papers. Disajikan pada Seminar Nasional Teknologi Pendidikan pada tanggal 18-19 Juli 2002 di Jakarta.

Soekartawi. 2002. Web based learning, kampus virtual masa depan. Harian Pelita, 29 Juli 2002.

Tucker, B. (2000). Web based learning and non-profit sector. White Paper Discussion of the Potential of Web based learning to Improve Non-Profit management Training, Washington, SmarterOrg, Inc., Diakses pada tanggal 20 September 2007 dari www.smarterorg.com.

Walgito, B. (1981). Pengantar psikologi umum. Yogyakarta: Yayasan Penerbitan Fakultas Psikologi UGM

Waller, V. and Wilson, J. (2001). A definition for web based learning. Newsletter of Open and Distance Learning Quality Control October 2001. Diakses pada tanggal 24 Sepetember 2007 dari _http:// www.odlqc.org.uk/odlqc/n19-e.html).

Wulf, K. (1996). Training via the internet: Where are we? Training and development 50 No. 5. Diakses pada tanggal 20 September 2007 dari http:// www.ericdigests.org/1997-1/distance.html

Young, K. (1956). Social psychology. $3^{\text {rd }}$ Edition. New York: Appleton-Century-Crofts, Inc.

\section{KETERANGAN PENULIS}

Eveline Siregar, lahir pada tanggal 13 Mei 1981. Saat ini menjabat sebagai dosen di Jurusan Teknologi Pendidikan Fakultas Ilmu Pendidikan Universitas Negeri Jakarta

Cecep Kustandi, lahir pada tanggal 13 Mei 1981. Saat ini menjabat sebagai dosen di Jurusan Teknologi Pendidikan Fakultas Ilmu Pendidikan Universitas Negeri Jakarta 